\title{
TEMPOROMANDIBULAR JOINT DISORDERS: A REPORT OF URHOBO PATIENTS IN ABRAKA, NIGERIA
}

\author{
Anibor Ese ${ }^{1 *}$, Mabiaku Yvonne Osaretin ${ }^{2}$, Jones-Dibie Brenmound ${ }^{3}$, Igwilo Chiamaka ${ }^{4}$

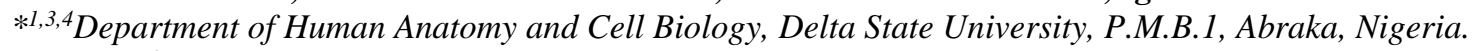 \\ ${ }^{2}$ Department of Surgery, Delta State University Teaching Hospital, Oghara, Nigeria. \\ *Department of Anatomy, Faculty of Basic Medical Sciences, Delta State University, Abraka, Nigeria. Phone number: \\ +2348131617679 and +2348180404966 E-mail address: eseovo2000@yahoo.com
}

*Corresponding Author: -

E-mail address: eseovo2000@yahoo.com

\begin{abstract}
: -
This study reconnoitered Temporomandibular Joint Disorders among the Urhobos in Abraka, Nigeria. The cross sectional study design was adopted for this study, and the cluster sampling technique was employed. Data was collected with the aid of a wellstructured questionnaire. Ethical clearance was obtained from the Research and Ethics Committee of the Department of Human Anatomy and Cell Biology, Delta State University, Abraka before data collection Data obtained was subjected to Statistical Package for Social Sciences (SPSS version 25) for the purpose of analysis. This study made use of three hundred and eightyfive subjects (57\% female and $43 \%$ male). The causes of temporomandibular joint disorders include accidents, assault, road traffic accidents, and falls. Temporomandibular joint disorder pointers ranged from pain in or around the ear, followed by pain when chewing, limited mouth opening, noise within temporomandibular joint when opening and closing the jaw, and jaw locking. Based on associated reasons for temporomandibular joint disorder, prior injury to the head and neck had the highest frequency. Significant gender difference was seen in the pointers of temporomandibular joint disorders $(p<0.05)$. The most frequent indicator of temporomandibular joint disorders among the Urhobo males scrutinized is limited mouth opening, while for the Urhobo females it is prior injury to the head and neck.
\end{abstract}

Keywords: Temporomandibular, joint, disorder, prevalence, gender 


\section{INTRODUCTION}

The disarticulation of the temporomandibular joint meniscus with clinical signs and indications, including pain and popping, was known in the first half of the 20th century. James Costen in 1934, distinguished a group of indications based on the ear and temporomandibular joint (Costen, 2004). The word "Costen's disorder" was coined because of his work. The term 'Temporomandibular joint pain dysfunction syndrome' was designed by Schwartz in the 1950s (Schwartz et al., 2009). Afterward, Ash and Ramford coined the word "Functional temporomandibular joint disturbances" (Ash and Ram, 2005).

Bilateral, diarthrodial, temporomandibular joints form the temporomandibular articulation (TMJ). Each joint is formed by a mandibular condyle and its corresponding temporal depression (glenoid fossa and articular eminence). The TMJ and its related structures play a vital part in mandibular development and dispersing stresses delivered by everyday tasks, such as chewing, gulping and talking (Zarb and Carlsson, 2009). TMJ disorders (TMD) are musculoskeletal degenerative conditions related to morphological and functional alterations (Laskin et al., 2003).

TMD includes intra-articular disc area and/or structure defects of the related musculature (Tanaka et al., 2008). Severe joint sounds, weakened or deviated range of movement, and cranial and/or muscle pain known as orofacial pain are indications and signs. TMJ disc pathology or malpositioning, termed "inner derangement" (ID) is experienced by up to 70 percent of TMD patients (Farrar and McCarty, 2009). Side effects of TMD occur extremely between the genders recorded in ladies with a much higher frequency; female to male proportions shift from 2:1 to 8:14 (Martins-Junior et al., 2010). The larger part of patients with side effects are between the ages of 20 and 50 years, an uncommon transference of a condition considered a degenerative illness (van Loon et al., 2002).

Where up to 25 percent of the populace may encounter TMD indications, only a diminutive rate of individuals affected seek care (Solberg et al., 2009). Signs of temporomandibular disorders happen in almost 60-70 percent of the common population, and however as it were almost one in four individuals with signs are really mindful of or report any complains (Graber, 2009).. Related works have been conducted in Nigeria and other parts of the world. The commonness of TMJ disorders have been shown to range from 41\%, 35\% and 31.4\% (Alshaban and Waheed, 2018; Alwarawreh et al., 2018; Ryalat et al., 2009).

Literature exploration disclosed dearth of information on pervasiveness of TMD among the Urhobos. Hence, the need to carry out a study on Temporomandibular Joint Disorders among the Urhobos in Abraka, Nigeria. Therefore, this study reconnoitered Temporomandibular Joint Disorders among individuals of the Urhobo ethnic group. Outcomes from this inquiry will guide the Oral/Maxillofacial Facial Surgeons in management of patients with TMDs.

\section{Materials and Methods}

Ethical clearance was obtained from the Research and Ethics Committee of Human Anatomy Department, Delta State University, Abraka. Informed consent was also obtained from the participants. This study adopted a cross sectional study design. The study sample comprised of both male and female individuals who are from the Urhobo ethnic group. These persons were within the ages of 15 years and above. This study was carried out in Abraka, Delta State, Nigeria. The sample size for this study is 384 and the cluster sampling technique was used. Sample size was determined with sample size calculation (Cochran, 2007).

The required data for this study was collected with the aid of a well-structured questionnaire. The results was analysed by means of Statistical Package for Social Sciences (SPSS) version 25.0. Results was presented in frequency distributions, pie charts and cross-tabulation. Chi-square gaged significant differences at a confidence level of $95 \%$ while $p \leq 0.05$ was considered as statistically significant.

\section{Results}

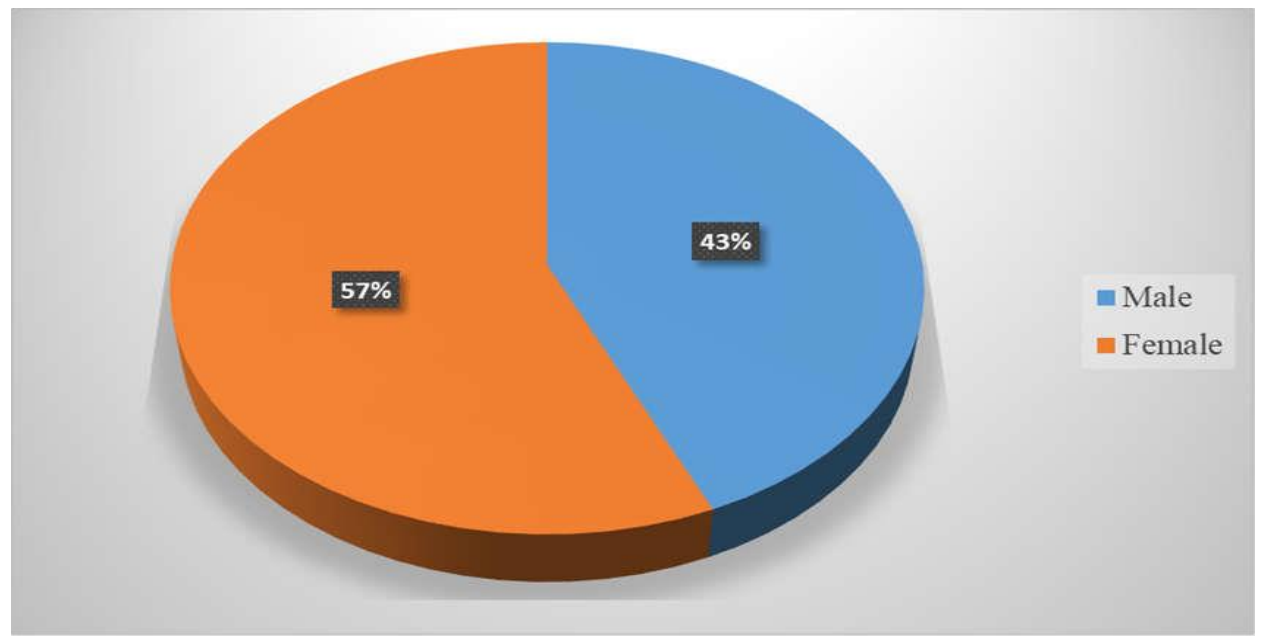

Figure 1. Gender distribution in the studied population

As shown in figure 1 , females were more than males. 


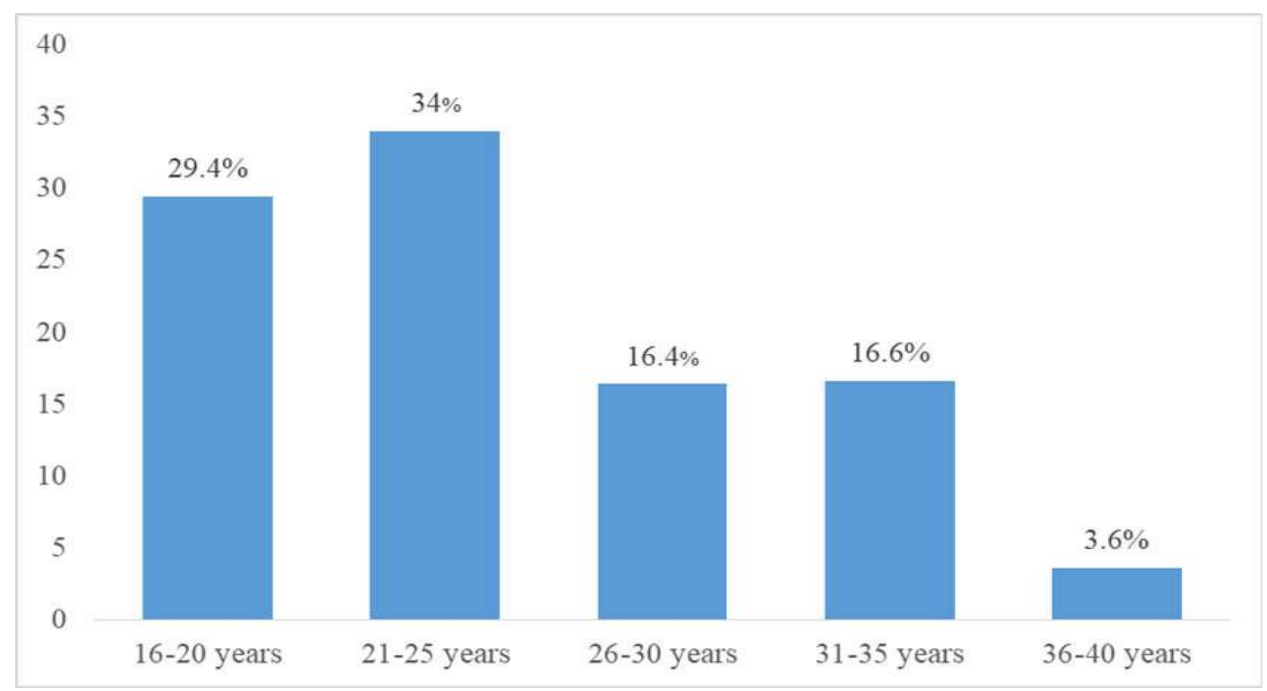

Figure 2. Age distribution in the studied population

As seen in figure 2, the subjects' age ranged from 16-40 years and the age range of 21-25 years was popular.

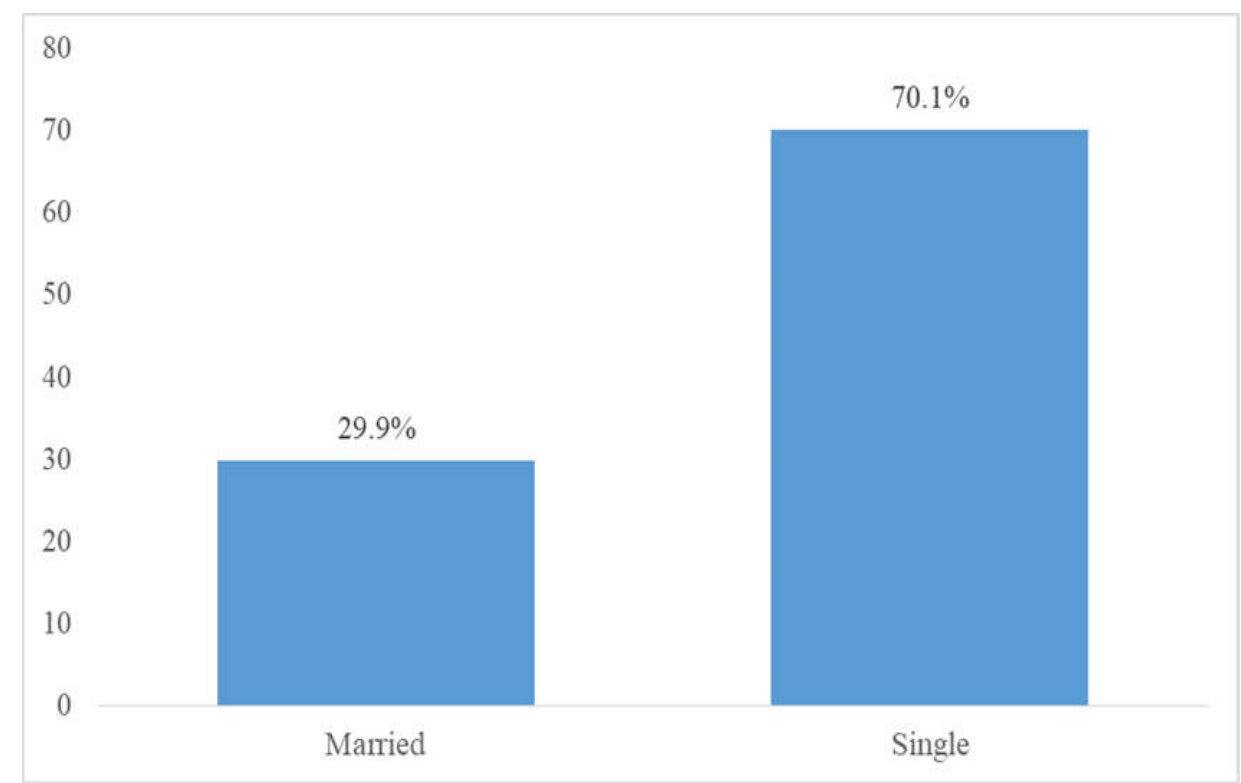

Figure 3. Distribution of respondents' marital statuses in the studied population

Figure 3 above shows that majority $(70.1 \%)$ of the respondents are singles while minority (29.9\%) are married.

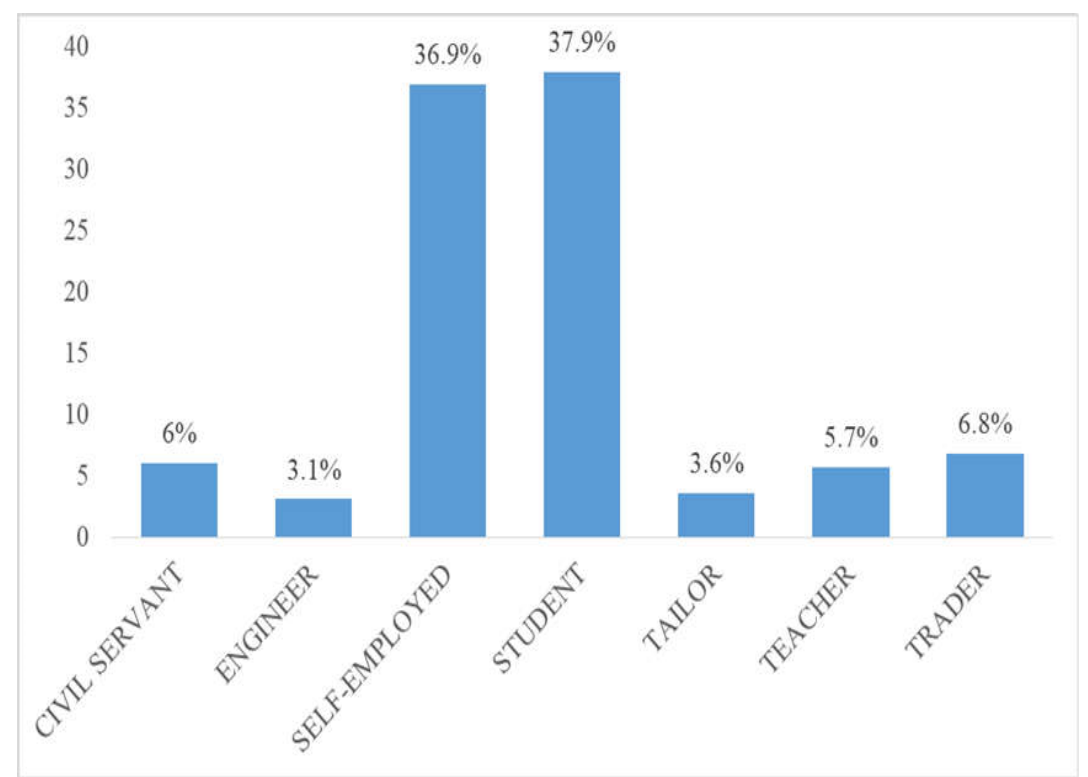

Figure 4. Distribution of respondents' occupations in the studied population 
Figure 4 above shows that the occupations of the subjects were such that students (37.9\%) were prevalent.

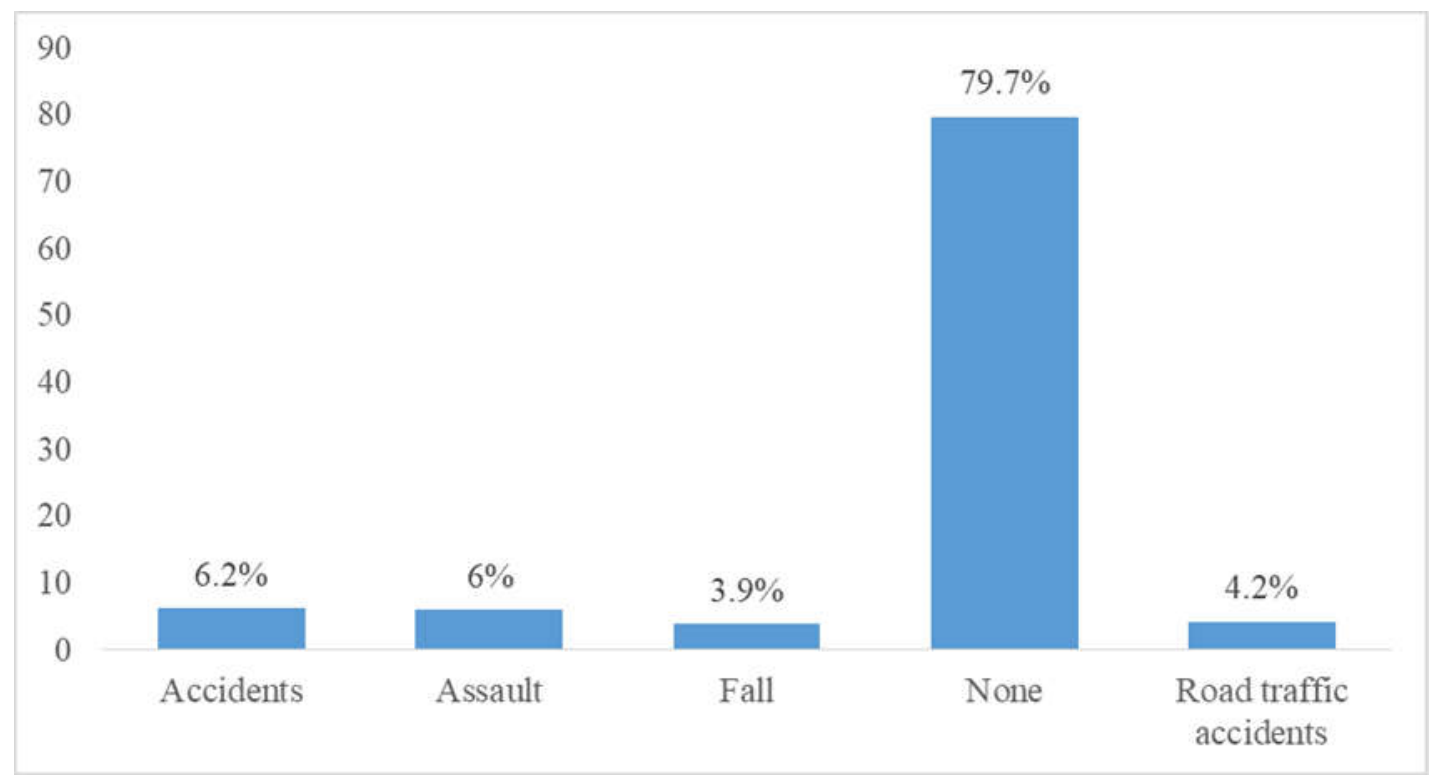

Figure 5. Causes of temporomandibular disorders in the studied population

As seen in figure 5, more than half of the respondents (79.7\%) were not aware of the causes of temporomandibular joint disorders.

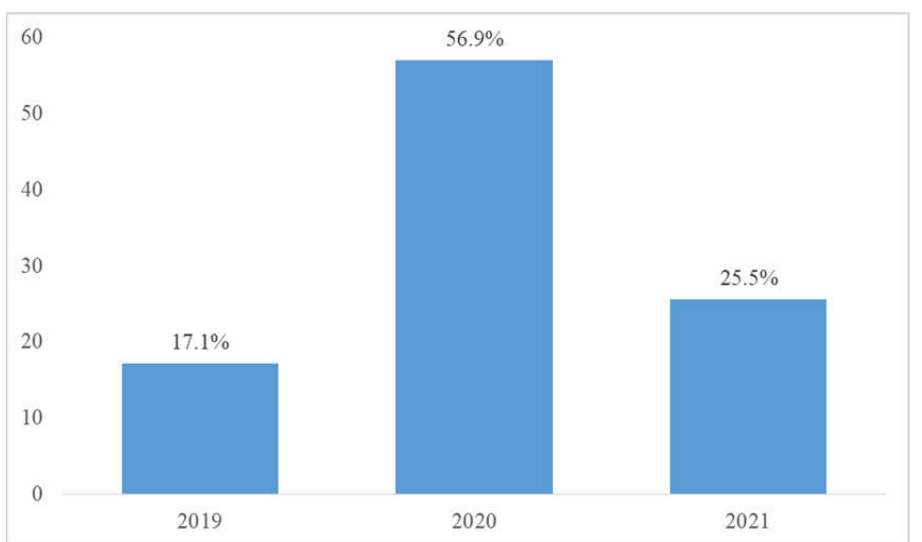

Figure 6: Distribution of time of injury in the studied population.

Figure 6 above shows that $2020(56.9 \%)$ is the year with the highest rate of injury and the year with minimal harm is 2019 $(17.1 \%)$.

Table 1. Pointers of temporomandibular joint disorders.

\begin{tabular}{lll}
\hline Pointers of temporomandibular joint disorders & $\begin{array}{l}\text { Frequency } \\
(\%)\end{array}$ \\
\hline & Yes & No \\
Limited mouth opening & $32(8.3)$ & $353(91.7)$ \\
$\begin{array}{l}\text { Noise within temporomandibular joint while opening } \\
\text { and closing jaw }\end{array}$ & $27(7.0)$ & $358(93.0)$ \\
Pain when chewing & $44(11.4)$ & $341(88.6)$ \\
Jaw locking & $15(3.9)$ & $370(96.1)$ \\
Pain in or around the ear & $50(13.0)$ & $335(87.0)$ \\
\hline Total & & \\
\hline
\end{tabular}

As seen in table 1 above the temporomandibular joint pointers ranged from pain in or around the ear (13\%), followed by pain when chewing $(11.4 \%)$, limited mouth opening $(8.3 \%)$, noise within temporomandibular joint when opening and closing jaw (7\%), and jaw locking (3.9\%). 
Table 2. Associated reasons for temporomandibular joint disorders.

\begin{tabular}{lll}
\hline Associated pointers & \multicolumn{2}{l}{ Frequency (\%) } \\
\hline & Yes & No \\
Prior injury to the head and neck & $81(21.0)$ & $304(79.0)$ \\
Presence of head and neck injury & $78(20.3)$ & $307(79.7)$ \\
\hline Total & & \\
\hline
\end{tabular}

As seen in table 2 associated reasons for temporomandibular joint disorders were prior injury to the head and neck with the highest frequency (21\%) and presence of head and neck injury (20.3\%).

Table 3. Indicators of temporomandibular joint disorders.

\begin{tabular}{lll}
\hline Temporomandibular joint disorders & Frequency (\%) \\
\hline Limited mouth opening & Yes & No \\
Noise within temporomandibular joint while opening and closing & $32(8.3)$ & $353(91.7)$ \\
jaw & $27(7.0)$ & $358(93.0)$ \\
Pain when chewing & $44(11.4)$ & $341(88.6)$ \\
Jaw locking & $15(3.9)$ & $370(96.1)$ \\
Pain in or around the ear & $50(13.0)$ & $335(87.0)$ \\
Prior injury to the head and neck & $81(21.0)$ & $304(79.0)$ \\
Presence of head and neck injury & $78(20.3)$ & $307(79.7)$ \\
\hline Total & &
\end{tabular}

The most prevalent indicator of temporomandibular joint disorder in table 3 is prior injury to the head and neck (21\%).

Table 4: Chi-square test of association between age and pointers of temporomandibular joint disorders

\begin{tabular}{|c|c|c|c|c|c|c|c|c|}
\hline $\begin{array}{lr}\text { Pointers } & \text { for } \\
\text { temporomandibular joint } \\
\text { disorders }\end{array}$ & $\begin{array}{l}16-20 \\
\text { years }\end{array}$ & $\begin{array}{l}21-25 \\
\text { years }\end{array}$ & $\begin{array}{l}26-30 \\
\text { years }\end{array}$ & $\begin{array}{l}31-35 \\
\text { years }\end{array}$ & $\begin{array}{l}36-40 \\
\text { years }\end{array}$ & $\begin{array}{l}\text { Chi- } \\
\text { square }\end{array}$ & df & $\begin{array}{l}\text { p- } \\
\text { value }\end{array}$ \\
\hline Limited mouth opening & - & $\begin{array}{l}2 \\
(1.2)\end{array}$ & $\begin{array}{l}22 \\
(13.1)\end{array}$ & $\begin{array}{l}8 \\
(4.8)\end{array}$ & - & 181.981 & 16 & 0.001 \\
\hline $\begin{array}{l}\text { Noise within } \\
\text { temporomandibular joint } \\
\text { while opening and closing } \\
\text { jaw }\end{array}$ & - & $\begin{array}{l}19 \\
(11.3)\end{array}$ & $\begin{array}{l}8 \\
(4.8)\end{array}$ & - & - & & & \\
\hline Pain when chewing & - & - & $\begin{array}{l}10 \\
(6.0)\end{array}$ & $\begin{array}{l}22 \\
(13.1)\end{array}$ & $\begin{array}{l}12 \\
(7.1)\end{array}$ & & & \\
\hline Jaw locking & - & $\begin{array}{l}13 \\
(7.7)\end{array}$ & - & $\begin{array}{l}2 \\
(1.2)\end{array}$ & - & & & \\
\hline Pain in or around the ear & $\begin{array}{l}21 \\
(12.5)\end{array}$ & $\begin{array}{l}8 \\
(4.8) \\
\end{array}$ & $\begin{array}{l}4 \\
(2.4) \\
\end{array}$ & $\begin{array}{l}11 \\
(6.5)\end{array}$ & $\begin{array}{l}6 \\
(3.6) \\
\end{array}$ & & & \\
\hline Total & $\begin{array}{l}21 \\
(12.5)\end{array}$ & $\begin{array}{l}42 \\
(25.0)\end{array}$ & $\begin{array}{l}44 \\
(26.2)\end{array}$ & $\begin{array}{l}43 \\
(25.6)\end{array}$ & $\begin{array}{l}18 \\
(10.7)\end{array}$ & & & \\
\hline
\end{tabular}

The pointers of temporomandibular joint disorder based on the age of the subjects showed that those who were within the ages of 16-20 years had the highest occurrence of pain in or around the ear, for 21-25 years it was noise within temporomandibular joint while opening and closing jaw, for subjects within the ages of 26-30 years it was limited mouth opening, for those who were within the ages of 31-35 years and 36-40 years it was pain when chewing respectively. There was a significant age difference in the pointers of temporomandibular joint disorders $(\mathrm{p}<0.05)$.

Table 5: Chi-square test of association between age and reasons for temporomandibular joint disorders

\begin{tabular}{|c|c|c|c|c|c|c|c|c|}
\hline $\begin{array}{ll}\text { Reasons } & \text { for } \\
\text { temporomandibular } \\
\text { joint disorders }\end{array}$ & $\begin{array}{l}16-20 \\
\text { years }\end{array}$ & $\begin{array}{l}21-25 \\
\text { years } \\
\text { Frequency }\end{array}$ & $\begin{array}{l}26-30 \\
\text { years } \\
(\%)\end{array}$ & $\begin{array}{l}31-35 \\
\text { years }\end{array}$ & $\begin{array}{l}36-40 \\
\text { years }\end{array}$ & $\begin{array}{l}\text { Chi- } \\
\text { square }\end{array}$ & df & p-value \\
\hline $\begin{array}{l}\text { Prior injury to the head } \\
\text { and neck }\end{array}$ & $\begin{array}{l}27 \\
(17.0)\end{array}$ & $13(8.2)$ & $8(5.0)$ & $\begin{array}{l}33 \\
(20.8)\end{array}$ & - & 27.380 & 3 & 0.001 \\
\hline $\begin{array}{l}\text { Presence of head and neck } \\
\text { injury }\end{array}$ & $13(8.2)$ & $17(10.7)$ & $\begin{array}{l}33 \\
(20.8)\end{array}$ & $\begin{array}{l}15 \\
(9.4)\end{array}$ & - & & & \\
\hline Total & $\begin{array}{l}40 \\
(25.2)\end{array}$ & $30(18.9)$ & $\begin{array}{l}41 \\
(25.8)\end{array}$ & $\begin{array}{l}48 \\
(30.2)\end{array}$ & - & & & \\
\hline
\end{tabular}

Table 5 disclosed that the reasons for temporomandibular joint disorders based on the age of the subjects showed that those who were within the ages of 16-20 years and 31-35 years had peak occurrence of prior injury to the head and neck, for those aged 21-25 years and 26-30 years it was the presence of head and neck injury. 
There was a significant relationship between age and the reasons for temporomandibular joint disorders $(\mathrm{p}<0.05)$.

Table 6: Chi-square test of association between age and impairments of temporomandibular joint disorders

\begin{tabular}{|c|c|c|c|c|c|c|c|c|}
\hline $\begin{array}{ll}\text { Impairments } & \text { of } \\
\text { temporomandibular } \\
\text { joint disorders }\end{array}$ & $\begin{array}{l}16-20 \\
\text { years }\end{array}$ & $\begin{array}{l}21-25 \\
\text { years } \\
\text { Frequency }\end{array}$ & $\begin{array}{l}26-30 \\
\text { years } \\
(\%)\end{array}$ & $\begin{array}{l}31-35 \\
\text { Years }\end{array}$ & $\begin{array}{l}36-40 \\
\text { years }\end{array}$ & $\begin{array}{l}\text { Chi- } \\
\text { square }\end{array}$ & df & $\begin{array}{l}\text { p- } \\
\text { value }\end{array}$ \\
\hline Limited mouth opening & - & $2(0.6)$ & $22(6.7)$ & $8(2.4)$ & - & 246.330 & 24 & 0.001 \\
\hline $\begin{array}{l}\text { Noise within } \\
\text { temporomandibular joint } \\
\text { while opening and closing } \\
\text { jaw }\end{array}$ & - & $19(5.8)$ & $8(2.4)$ & - & - & & & \\
\hline Pain when chewing & - & - & $10(3.1)$ & $22(6.7)$ & $\begin{array}{l}12 \\
(3.7)\end{array}$ & & & \\
\hline Jaw locking & - & $13(4.0)$ & - & $2(0.6)$ & - & & & \\
\hline Pain in or around the ear & $\begin{array}{l}21 \\
(6.4)\end{array}$ & $8(2.4)$ & $4(1.2)$ & $11(3.4)$ & $6(1.8)$ & & & \\
\hline $\begin{array}{l}\text { Prior injury to the head } \\
\text { and neck }\end{array}$ & $\begin{array}{l}27 \\
(8.3)\end{array}$ & $13(4.0)$ & $8(2.4)$ & $33(10.1)$ & - & & & \\
\hline $\begin{array}{l}\text { Presence of head and neck } \\
\text { injury }\end{array}$ & $\begin{array}{l}13 \\
(4.0)\end{array}$ & $17(5.2)$ & $33(10.1)$ & $15(4.6)$ & - & & & \\
\hline Total & $\begin{array}{l}61 \\
(18.7)\end{array}$ & $72(22.0)$ & $85(26.0)$ & $91(27.8)$ & $\begin{array}{l}18 \\
(5.5)\end{array}$ & & & \\
\hline
\end{tabular}

Table 6 showed that there is a significant association between age and incapacitations of temporomandibular joint disorders $(\mathrm{p}<0.05)$.

Table 7: Chi-square test of association between gender and pointers of temporomandibular joint disorders

\begin{tabular}{|c|c|c|c|c|c|}
\hline $\begin{array}{lr}\text { Pointers } & \text { of } \\
\text { temporomandibular joint } \\
\text { disorders }\end{array}$ & $\begin{array}{l}\text { Male } \\
\text { Frequency }\end{array}$ & $\begin{array}{l}\text { Female } \\
(\%)\end{array}$ & Chi-square & df & p-value \\
\hline Limited mouth opening & $32(19.0)$ & - & 59.837 & 4 & 0.001 \\
\hline $\begin{array}{l}\text { Noise within } \\
\text { temporomandibular joint } \\
\text { while opening and closing } \\
\text { jaw }\end{array}$ & $27(16.1)$ & - & & & \\
\hline Pain when chewing & $18(10.7)$ & $26(15.5)$ & & & \\
\hline Jaw locking & $15(8.9)$ & - & & & \\
\hline Pain in or around the ear & $24(14.3)$ & $26(15.5)$ & & & \\
\hline Total & $116(69.0)$ & $52(31.0)$ & & & \\
\hline
\end{tabular}

Table 7 showed that based on gender, the pointers of temporomandibular joint disorders among male subjects indicated a high occurrence of limited mouth opening, while for females it was pain when chewing and pain in or around the ear. There was a significant gender difference in the pointers of temporomandibular joint disorders $(\mathrm{p}<0.05)$.

Table 8: Chi-square test of association between gender and reasons for temporomandibular joint disorders

\begin{tabular}{|c|c|c|c|c|c|}
\hline $\begin{array}{l}\text { Reasons } \\
\text { temporomandibular } \\
\text { disorder }\end{array}$ & $\begin{array}{l}\text { Male } \\
\text { Frequency }\end{array}$ & $\begin{array}{l}\text { Female } \\
(\%)\end{array}$ & Chi-square & df & p-value \\
\hline Prior injury to the head and neck & $27(17.0)$ & $54(34.0)$ & 0.030 & 1 & 0.863 \\
\hline Presence of head and neck injury & $25(15.7)$ & $53(33.3)$ & & & \\
\hline Total & $52(32.7)$ & $107(67.3)$ & & & \\
\hline
\end{tabular}

Table 8 showed that based on gender, the most common reason for the complications of temporomandibular joint disorder among male and female subjects was prior injury to the head and neck. An insignificant association occurred between gender and the reasons for temporomandibular joint disorders $(\mathrm{p}>0.05)$. 
Table 9: Chi-square test of association between gender and the impairments of temporomandibular joint disorders

\begin{tabular}{|c|c|c|c|c|c|}
\hline $\begin{array}{lr}\text { Impairments } & \text { of } \\
\text { temporomandibular joint } \\
\text { disorders }\end{array}$ & $\begin{array}{l}\text { Male } \\
\text { Frequency }\end{array}$ & $\begin{array}{l}\text { Female } \\
(\%)\end{array}$ & Chi-square & df & p-value \\
\hline Limited mouth opening & $\begin{array}{l}32 \\
(9.8)\end{array}$ & - & 94.410 & 6 & 0.001 \\
\hline $\begin{array}{l}\text { Noise within } \\
\text { temporomandibular joint } \\
\text { while opening and closing } \\
\text { jaw }\end{array}$ & $\begin{array}{l}27 \\
(8.3)\end{array}$ & - & & & \\
\hline Pain when chewing & $\begin{array}{l}18 \\
(5.5)\end{array}$ & $\begin{array}{l}26 \\
(8.0)\end{array}$ & & & \\
\hline Jaw locking & $\begin{array}{l}15 \\
(4.6)\end{array}$ & - & & & \\
\hline Pain in or around the ear & $\begin{array}{l}24 \\
(7.3)\end{array}$ & $\begin{array}{l}26 \\
(8.0)\end{array}$ & & & \\
\hline $\begin{array}{l}\text { Prior injury to the head and } \\
\text { neck }\end{array}$ & $\begin{array}{l}27 \\
(8.3)\end{array}$ & $\begin{array}{l}54 \\
(16.5)\end{array}$ & & & \\
\hline $\begin{array}{l}\text { Presence of head and neck } \\
\text { injury }\end{array}$ & $\begin{array}{l}25 \\
(7.6)\end{array}$ & $\begin{array}{l}53 \\
(16.2)\end{array}$ & & & \\
\hline Total & $168(51.4)$ & $159(48.6)$ & & & \\
\hline
\end{tabular}

It was shown in table 9 that based on gender, the commonest impediment of temporomandibular joint disorders among male subjects was limited mouth opening while for female subjects, it was prior injury to the head and neck. There was a significant gender difference in the impairments of temporomandibular joint disorders $(\mathrm{p}<0.05)$.

\section{Discussion}

Three hundred and eighty-five subjects (57\% females and $43 \%$ males) partook in this study. Majority of the partakers were within the ages of 21-25 years, single, and were students. This finding was not supported by that of Alshaban and Waheed (2018) who found that most of their study participants were males. Ilyas et al. (2019) found that the mean age of their study participants was $26.5 \pm 3.4$ years. The current inquiry was however buttressed by the finding of Teuta et al. (2017) who encountered more female participants than male participants; and Habib et al., (2015) who documented mean age of $21.9 \pm 1.79$ years among their participators. The mechanisms underlying these sex-related differences remain obscure and likely involve both psychologic and physiologic factors.

More than half of the research participators were not aware of the cause of temporomandibular joint disorders. The causes of temporomandibular joint disorders in this scrutiny included accidents, assault, road traffic accidents, and falls. The year with the highest rate of injury as seen in this study was 2020. This scrutiny was not in line with that of Ashwin and Siri (2018) who found that just few of the subjects were not aware of the causes of temporomandibular joint disorders. Robin and Chiomento (2010) reported that tooth clenching, stress, extraction of wisdom teeth, and endotracheal intubation were the causes of temporomandibular joint disorders.

The differences seen between this current research and that of Ashwin and Siri (2018) as well as Robin and Chiomento (2010) could be due to regional differences.

This present study found that the pointers of temporomandibular joint disorders ranged from pain in or around the ear, followed by pain when chewing, limited mouth opening, noise within temporomandibular joint when opening and closing jaw, and jaw locking. Based on associated reasons for temporomandibular joint disorder prior injury to the head and neck had the highest frequency. These findings were similar to those of Bugaighis et al., (2017) who reported that more than half of their research participants experienced pain and the least symptom was opening and closing jaw, and jaw locking; also Robin and Chiomento (2010) found that the prevalence of articular and muscular symptoms were notable.

The pointers of temporomandibular joint disorders in this study as regards the age of the subjects showed that those who were within the ages of 16-20 years had the highest occurrence of pain in or around the ear, for 21-25 years it was noise within temporomandibular joint while opening and closing jaw, for subjects within the ages of 26-30 years it was limited mouth opening, for those who were within the ages of 31-35 years and 36-40 years it was pain when chewing respectively. There was a significant age difference in the pointers of temporomandibular joint disorders $(\mathrm{p}<0.05)$. This finding was not in accord with that of Renato et al., (2019) who reported that there was no significant age difference in the pointers of temporomandibular joint disorders ( $p>0.05$ ); also Habib et al., (2015) reported that the incidence of pain when chewing was more prevalent among young adults. These differences could have been due to differences in the study area.

This current study showed that with reference to gender, the pointers of impediments of temporomandibular joint disorders among male subjects were such that there was peak occurrence of limited mouth opening, while for females it was pain when chewing and pain in or around the ear. There was a significant gender difference in the pointers of temporomandibular joint disorders $(\mathrm{p}<0.05)$. This finding was not in harmony with that of Renato et al., (2019) who reported that there was no significant gender difference in the pointers of temporomandibular joint disorders ( $p>0.05$ ).

The correspondences and variances portrayed in the researches appraised are owed to age, gender, race, ethnicity, methodology and environmental concerns. An apparent drawback of this inquiry is the age declaration by subjects as birth records were not sighted. 


\section{Conclusion}

The most frequent indicator of temporomandibular joint disorders among the Urhobo males scrutinized is limited mouth opening, while for the Urhobo females it is prior injury to the head and neck. There was a considerable gender variance in the occurrence of temporomandibular joint disorders. There was a remarkable age variance in the indicators of temporomandibular joint disorders.

\section{References}

[1].Aggarwal, V. R., Lovell, K., Peters, S., Javidi, H., Joughin, A. and Goldthorpe, J. (2011). "Psychosocial Interventions for the Management of Chronic Orofacial Pain". The Cochrane Database of Systematic Reviews; (11): CD008456.

[2].Alshaban, K. K. and Waheed, Z. G. A. (2018). Prevalence of TMJ Disorders among the Patients Attending the Dental Clinic of Ajman University of Science and Technology-Fujairah Campus, UAE. Int J Dent; 1-5.

[3].Bath-Balogh, M. and Fehrenbach, M. J. (2011). Illustrated Dental Embryology, Histology, and Anatomy. Elsevier Saunders. p. 266.

[4].Bugaighis, E., Elgehani, R., Orafi, M. and Elatrash, A. (2017). The prevalence of Temporomandibular Disorders among a Group of Libyan Dental Students. Libyan International Medical University Journal; 2: 6473.

[5].Cairns, B. E. (2010). "Pathophysiology of TMD pain--basic mechanisms and their implications for pharmacotherapy". Journal of Oral Rehabilitation; 37 (6): 391-410.

[6].Carlsson, G. E. and LeResche, L. (2005). Epidemiology of Temporomandibular Disorders. In: Sessle BJ, Bryant P, Dionne R, editors. Temporomandibular disorders and related pain conditions. Seattle: International Association of the Study of Pain. Press; pp. 497-506.

[7].Farrar, W. B. and McCarty, W. L. (2009). The TMJ Dilemma. Journal of Ala Dentistry Association; 63: $19-26$.

[8].Fehrenbach, A. and Herring, S. (2012). Illustrated Anatomy of the Head and Neck, Elsevier; 118.

[9].Graber, R. P. (2009). In: Dentofacial Orthopedics with Functional Appliances. 2nd ed. St. Louis: Mosby. Functional Analysis- Examination of Temporomandibular Joint and Condylar Movement; pp. 135-40.

[10]. Habib, S. R., Qasim, M., Rifaiy, A., Habib, A. K., Alsaif, A. and Alshalan, A. (2015). Prevalence and Severity of Temporomandibular Disorders Among University Students in Riyadh Production and Hosting. The Saudi Dentistry Journal; 27:125-30.

[11]. Ilyas, M., Kifayat, F., Gul, F., Khan, S., Saeed, S. and Danish, A. K. (2019). Prevalence and severity of temporomandibular joint disorders among house officers \& post-graduate residents of private \& public sector medical hospitals in Peshawar, Pakistan. J Gandhara Medical Dentistry Science; 6 (1): 1-5.

[12]. Laskin, D. M., Greenfield, W. and Gale, E. (2003). The President's Conference on the Examination, Diagnosis, and Management of Temporomandibular Disorders. Chicago: American Dental Association.

[13]. Lee, K., Wu, Y., Chien, W., Chung, C., Chen, L. and Shieh, Y. (2020). The Prevalence of First-Onset Temporomandibular Disorder in Low Back Pain and Associated Risk Factors: A Nationwide Population-Based Cohort Study with a 15-Year Follow-Up. Medical Journal; 99 (3): 18686.

[14]. Lucky, O. A. (2014). The Spirit of Community Service and Development of Urhoboland: The UmiaghwaAvwraka Experience. Urhobo Historical Society; 1-10.

[15]. Luther, F., Layton, S. and McDonald, F. (2010). McDonald F (ed.). "Orthodontics for Treating Temporomandibular Joint (TMJ) Disorders". The Cochrane Database of Systematic Reviews; (7): CD006541

[16]. Moore, K. L., Dalley, A. F., and Agur, A. M. (2017). Clinically Oriented Anatomy. Lippincott Williams \& Wilkins

[17]. Mujakperuo, H.R., Watson, M., Morrison, R. and Macfarlane, T. V. (2010). "Pharmacological Interventions for Pain in Patients with Temporomandibular Disorders". The Cochrane Database of Systematic Reviews; (10): CD004715.

[18]. Nozawa-Inoue, K., Amizuka, N., Ikeda, N., Suzuki, A., Kawano, Y. and Maeda, T. (2003). "Synovial Membrane in the Temporomandibular Joint--Its Morphology, Function and Development". Archives of Histology and Cytology; 66 (4): 289-306.

[19]. Okeson, J. P. (2003). In: Management of temporomandibular disorders and occlusion. 5th ed. St. Louis: Mosby. Treatment of temporomandibular joint disorders; pp. 413-35.

[20]. Okeson, J. P. (2009). Orthodontic Therapy and Patient with Temporomandibular Disorder. In: Graber, Vanasdall, Vig, editors. Orthodontics current principles and techniques. 4th ed. St. Louis: Mosby; pp. 331-44. 